Indexed by

\title{
Scopus
}

\section{ANALYSIS OF THE EFFICIENCY OF USING THE POLYCRYSTALLINE AND AMORPHOUS PV MODULE IN THE TERRITORY OF INDONESIA}

Crossref

\section{Sugeng Hadi Susilo}

State Polytechnic of Malang, Department Mechanical, Engineering, Indonesia

\author{
Asrori Asrori \\ State Polytechnic of Malang, \\ Department Mechanical, \\ Engineering, \\ Indonesia
}

\author{
Gumono Gumono \\ State Polytechnic of Malang, \\ Department Mechanical, \\ Engineering, \\ Indonesia
}

Key words: efficiency, photovoltaic module, polycrystalline, amorphous, actual power doi:10.5937/jaes0-31607

Cite article:

Hadi Susilo S., Asrori A., Gumono G. (2022) ANALYSIS OF THE EFFICIENCY OF USING THE POLYCRYSTALLINE AND AMORPHOUS PV MODULE IN THE TERRITORY OF INDONESIA, Journal of Applied Engineering Science, 20(1), 239 - 245, DOI:10.5937/ jaes0-31607 


\title{
ANALYSIS OF THE EFFICIENCY OF USING THE POLYCRYSTALLINE AND AMORPHOUS PV MODULE IN THE TERRITORY OF INDONESIA
}

\author{
Sugeng Hadi Susilo*, Asrori Asrori, Gumono Gumono \\ State Polytechnic of Malang, Department Mechanical, Engineering, Indonesia
}

The article discusses the efficiency analysis of the Photovoltaic (PV) modules, namely polycrystalline and amorphous. The performance in question is the instantaneous efficiency obtained from the measurement of the voltage (V) and current (I) data generated by the two PV modules. In addition, it aims to determine the effect of solar radiation on the output power of polycrystalline and amorphous PV modules. The research was conducted in September 2020, with the outdoor location of the Department of Mechanical Engineering, State Polytechnic of Malang (7,944 ${ }^{\circ}$ S; $\left.112,613^{\circ} \mathrm{E}\right)$. The independent variables in this study are the current and voltage generated, and the type of PV Module (Polycrystalline and Amorphous). The dependent variable in this study is the actual power and instantaneous efficiency. Measurement of solar radiation using the Glentest SM 206 Solar Power Meter. Measurement of Current and Voltage using a Digital V-I Meter. The results showed that the greater the solar radiation, the higher the actual power and efficiency generated by the PV Module. Polycrystalline PV Modules are capable of producing higher average actual power and average instantaneous efficiency, which are $86.83 \mathrm{~W}$ and $11.92 \%$ when compared to Amorphous PV Modules, which are $43.88 \mathrm{~W}$ and $6.01 \%$.

Key words: efficiency, photovoltaic module, polycrystalline, amorphous, actual power

\section{INTRODUCTION}

The availability of sufficient energy is one of the problems for countries in the world, including Indonesia. The potential of solar energy in Indonesia is around 4.8 $\mathrm{kWh} / \mathrm{m} 2 /$ day. So that the use of solar energy becomes an alternative source of new and renewable energy. The two most widely produced types of solar panels are Mono Crystalline and Poly Crystalline. The colour of the monocrystalline solar panel is flat black, the shape of the silicon wafer is like a box with cut corners. Each solar cell contains a silicon wafer made of single-crystal silicon. The single crystals are formed using the Czochralski method, in which the 'seed' crystals are placed into vats of pure liquid silicon at high temperatures. The seed is then arranged and liquid silicon forms around it, creating a single crystal. The large crystals, also called ingots, are then sliced into thin wafers that are used to make solar cells. Monocrystalline solar panels have efficiencies ranging from $17 \%$ to $22 \%$. Because monocrystalline solar cells are made of single crystals of silicon, electrons can flow more easily through the cells, making PV cells more efficient than other types of solar panels. While polycrystalline panels are also called multicrystalline panels. The multiple silicon crystals in each solar cell make it harder for electrons to flow. This crystal structure makes the efficiency level of polycrystalline panels lower than monocrystalline panels. The efficiency ratings of polycrystalline panels typically range from $15 \%$ to $17 \%$. In addition, there are solar panels of the Amorphous Silicon type which used to have a bad reputation [1], [2]. However, with the development of technology, this type has several advantages over the Silicon Crystalline type. This becomes the basis for researching the performance comparison of Poly Crystalline and Amorphous PV Modules, especially in Indonesia. The results of this study are expected to determine the characteristics of the two types of PV modules [3], [4]. Research on the efficiency of solar cells has been carried out by many researchers. [5], [6] Researched by analyzing the effect of solar radiation and time on variations in solar cell temperature. The research was conducted in two different countries, namely Hong Kong and Egypt. The results show that the solar cell temperature is a correlation function of the maximum global solar radiation value, cooling coefficient, optical parameters, physical parameters and geometric parameters of solar cells. [7], [8] Analyzing the efficiency of mono and polycrystalline solar panels for water pump applications in Brazil. The results showed that polycrystalline resulted in higher efficiency and lower cost per volume of water pumped. The efficiency of polycrystalline and monocrystalline were $9.40 \%$ and $6.57 \%$, respectively. While this research is a series of previous studies by our team, namely examining the performance of several types of solar modules (Mono, Poly and amorphous). Previous studies compared the surface temperature characteristics to performing mono and polycrystal types [9]. While this research is limited to solar radiation variables to compare the performance of the amorphous and polycrystalline types. We hypothesize that the amorphous type is very sensitive to the level of solar radiation. In cloudy conditions (low solar radiation). The output power characteristic of the amorphous type drops drastically to zero (0), which is showed 
by a significant voltage drop. This differs from the crystalline type (mono and poly) where in cloudy conditions the output power is there even though it is small. The other variables (Surface Module Temperature, Humidity, Wind Velocity) are our next project for research. As for the performance comparison between mono and polycrystalline. The results show that in sunny weather in Malang, Indonesia, the two do not show a significant difference in performance. Research shows the normalized power output efficiency of the mono and polycrystalline by $70.79 \%$ and $66.33 \%$, respectively. So in this study, it made only a comparison between polycrystalline and amorphous types. This is because it predicted both types to have lower efficiency than monocrystalline.

\section{THEORY OF PV MODULE PERFORMANCE}

The performance testing of PV module products can be conducted by two methods, namely through laboratory tests (indoor) and experimental tests in the field (outdoor), using standard tests according to IEC 61215 [10]. The standard conditions in the STC include (i) solar irradiance $=1000 \mathrm{~W} / \mathrm{m}^{2}$, which is the peak amount of solar radiation on a surface directly facing the sun on a cloudless day. (ii) surface temperature $=25{ }^{\circ} \mathrm{C}$ (iii) air mass $(A M)=1.5 \mathrm{G}$, is a simulated light spectrum condition close to sunlight. This test method helps in designing the solar panel installation system. It can analyze the performance of PV modules from different manufacturers, besides that it can predict the amount of electrical energy generated by PV modules. However, this prediction also needs to consider external parameters. These parameters include location, operating temperature, radiation level, radiation spectrum, wind speed, angle of incidence and several other factors. This causes the actual efficiency to differ from the efficiency measured in the manufacturer's manual [11]. Several factors that affect the performance parameters of PV Modules include surface area, solar radiation, ambient temperature, weather, and other factors. The output parameters of most solar panels use Standard Test Conditions (STC). The efficiency of the PV module $\left(\eta_{\mathrm{STC}}\right)$ under STC conditions can be calculated based on equation 1 [12].

$\eta_{S T C}=\left(\frac{P_{\max }}{A \times 1000}\right) \times 100$

where Pmax is the maximum power $(\mathrm{W})$ by given equation (2);

$P_{\max }=V_{\max } \times I_{\max }$

Where: Pmax, Vmax, Imax are the maximum of power, voltage and current, respectively. It's in the STC condition (Manufacturer's Data Sheets), $\eta_{\mathrm{STC}}$ is the panel efficiency in the STC condition (\%), and A is the PV Module area $\left(\mathrm{m}^{2}\right)$. The instability of the PV module output value depends on several factors including solar radiation, module temperature and ambient temperature.
Therefore, in implementing the PV module installation, measurements need to be made. This is to find out the actual value of the PV Module. The performance parameters of the PV module consist of the module Instantaneous Efficiency $\left(\eta_{\mathrm{i}}\right)$ and normalized power output efficiency $\left(\eta_{n}\right)$, see equations (3) and (4) [13].

$\eta_{i}=\frac{P_{a c t}}{G \times A} \times 100$

and,

$\eta_{n}=\frac{P_{a c t}}{P_{\max }} \times 100$

$\eta_{i}$ is the measured conversion efficiency of the PV Module $(\%), \eta_{n}$ is the normalized power efficiency is the ratio of the rated output power to the maximum power under STC conditions (\%), Pact is the rated output power of the PV Module (Watts), $G$ is the solar radiation $\left(\mathrm{W} / \mathrm{m}^{2}\right)$ and $A$ is the area of the PV Module $\left(\mathrm{m}^{2}\right)$.

\section{MATERIAL AND METHODS}

The research was conducted in the outdoor department of Mechanical Engineering, State Polytechnic of Malang $(7,944 \mathrm{~S} ; 112,613 \mathrm{E})$. Solar radiation or the intensity of sunlight in question is Global Horizontal Irradiance (GHI). GHI was measured using the Glentest SM 206 Solar Power Meter $\left(\mathrm{W} / \mathrm{m}^{2}\right)$. Actual Power (Pact) is the output power of the PV module when connected to a power load (DC lamp). Pact is obtained from reading the voltage and current of the $A / V$ meter. The intensity of the sun's rays when the weather is sunny or cloudy. $\mathrm{GHI}$ measurements are carried out at intervals of every 10 minutes with a reading range between 450-1100 W/ $\mathrm{m}^{2}$. The peak power (Pmax) of each PV module used is $100 \mathrm{Wp}$ and $80 \mathrm{Wp}$. Figure 1 shows the experimental setup, and table 1 shows the technical specifications of the PV Module.

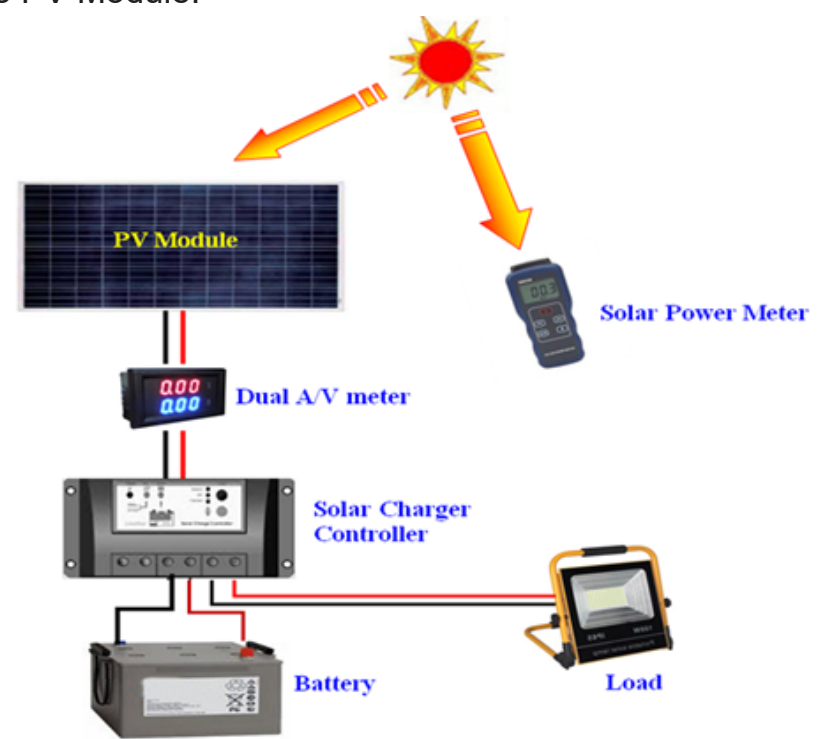

Figure 1: Experimental setup

Istraživanja i projektovanja za privredu ISSN 1451-4117 Journal of Applied Engineering Science Vol. 20, No. 1, 2022 
Table 1: Technical specification of the PV Modules tested

\begin{tabular}{|c|c|c|}
\hline & Polycrystalline & Amorphous \\
\hline Dimensions & $\begin{array}{c}1000 \times 670 \\
\mathrm{~mm}\end{array}$ & $\begin{array}{c}1000 \times 400 \\
\mathrm{~mm}\end{array}$ \\
\hline Peak power (Pmax) & $100 \mathrm{Wp}$ & $80 \mathrm{Wp}$ \\
\hline Cell efficiency & $14.5 \%$ & $\mathrm{~N} / \mathrm{A}$ \\
\hline Max power volt. (Vmp) & $17.8 \mathrm{~V}$ & $17.4 \mathrm{~V}$ \\
\hline $\begin{array}{c}\text { Max power current } \\
\text { (Imp) }\end{array}$ & $5.62 \mathrm{~A}$ & $4.60 \mathrm{~A}$ \\
\hline Open circuit volt. (Voc) & $22.4 \mathrm{~V}$ & $22.4 \mathrm{~V}$ \\
\hline $\begin{array}{c}\text { Short circuit current } \\
\text { (Isc) }\end{array}$ & $5.95 \mathrm{~V}$ & $4.91 \mathrm{~A}$ \\
\hline Power Tolerance & $\pm 3 \%$ & $\mathrm{~N} / \mathrm{A}$ \\
\hline Max. system voltage & $600 \mathrm{~V} \mathrm{DC}$ & $1000 \mathrm{~V} \mathrm{DC}$ \\
\hline Series fuse rating (A) & 10 & N/A \\
\hline NOCT & $47 \mathrm{oC}$ & N/A \\
\hline Power Temp. Coeff. (v) & $-0.45 \% / \mathrm{OC}$ & N/A \\
\hline
\end{tabular}

\section{RESULTS AND DISCUSSION}

\section{The Potential of Solar Radiation in Indonesia}

Indonesia is an equatorial country with latitudes $11^{\circ} \mathrm{S}$ $6^{\circ} \mathrm{N}$ and longitudes $95^{\circ} \mathrm{E}-141^{\circ} \mathrm{E}$. Indonesia has a tropical climate with two seasons throughout the year, namely the dry season and the rainy season. Because of its geographical location, Indonesia has a large enough potential for solar energy. This is because it gets sunlight all year round. Table 2 shows global solar radiation data for several cities in Indonesia. The data shows the average global solar radiation per day $\mathrm{kWh} / \mathrm{m} 2$ for each month of the year based on field measurements. The data was taken for 3 years, namely 2017-2020. Solar energy resources spread throughout Indonesia have the potential for Solar Power Generation. The potential for electrical energy $(\mathrm{kWh})$ that can be generated by the installation of solar panels (Photovoltaic modules) throughout Indonesia can be seen in Figure 2. Figure 2 shows that the installation of a PV Module with a capacity of $1 \mathrm{kWp}$ in Indonesia can generate daily energy between $3.4 \mathrm{kWh}$ to $4.2 \mathrm{kWh}$. Thus, the potential for electrical energy generated by the solar rooftop installation with a capacity of 1 $\mathrm{kWp}$ suffices to meet the electrical energy consumption of each household. It based this on data on the average electrical energy need per capita of the Indonesian population during 2018, which was only 1,064 kWh. Actual power characteristics and efficiency of polycrystalline PV Modules. Table 3 shows the measurement results of solar radiation $(\mathrm{G})$, output current $(\mathrm{I})$ and output voltage $(\mathrm{V})$ of the polycrystalline PV Module.

Table 2: The Average of Global Solar Radiation ( $\mathrm{kWh} / \mathrm{m}^{2} /$ day) in several cities in Indonesia

\begin{tabular}{|c|c|c|c|c|c|c|c|c|c|c|c|c|}
\hline CITY & JAN & FEB & MAR & APR & MAY & JUN & JUL & AUG & SEPT & OCT & NOV & DEC \\
\hline BALI & 5.489 & 5.639 & 6.169 & 5.950 & 5.839 & 5.561 & 5.861 & 6.550 & 7.189 & 7.269 & 6.561 & 5.700 \\
\hline $\begin{array}{c}\text { BANDAR } \\
\text { LAMPUNG }\end{array}$ & 4.831 & 4.919 & 5.031 & 4.889 & 4.511 & 4.339 & 4.411 & 4.850 & 5.300 & 5.211 & 4.961 & 4.703 \\
\hline BANDUNG & 4.311 & 4.581 & 5.031 & 5.011 & 4.850 & 4.669 & 4.969 & 5.531 & 5.950 & 5.689 & 5.050 & 4.719 \\
\hline BATAM & 4.250 & 5.131 & 5.031 & 4.831 & 4.531 & 4.331 & 4.250 & 4.369 & 4.489 & 4.519 & 4.019 & 3.769 \\
\hline BEKASI & 4.250 & 4.750 & 5.189 & 5.219 & 5.100 & 4.931 & 5.261 & 5.919 & 6.289 & 5.811 & 5.000 & 4.450 \\
\hline BOGOR & 4.189 & 4.289 & 4.800 & 4.831 & 4.711 & 4.564 & 4.800 & 5.239 & 5.600 & 5.339 & 4.781 & 4.581 \\
\hline DEPOK & 4.250 & 4.750 & 5.189 & 5.219 & 5.100 & 4.931 & 5.261 & 5.919 & 6.289 & 5.811 & 5.000 & 4.450 \\
\hline JAKARTA & 4.250 & 4.739 & 5.189 & 5.219 & 5.100 & 4.931 & 5.261 & 5.919 & 6.289 & 5.811 & 5.000 & 4.450 \\
\hline MAKASAR & 4.550 & 4.811 & 5.369 & 5.711 & 5.619 & 5.369 & 5.581 & 6.289 & 6.711 & 6.539 & 5.561 & 4.389 \\
\hline MALANG & 4.400 & 4.419 & 4.581 & 4.611 & 4.589 & 4.419 & 4.564 & 5.089 & 5.631 & 5.639 & 5.050 & 4.683 \\
\hline MEDAN & 4.889 & 5.289 & 5.331 & 4.911 & 4.772 & 4.989 & 4.719 & 4.531 & 4.431 & 4.181 & 4.119 & 4.269 \\
\hline PADANG & 4.869 & 5.281 & 5.200 & 5.111 & 5.031 & 4.961 & 4.850 & 4.831 & 4.900 & 4.842 & 4.500 & 4.550 \\
\hline PALEMBANG & 4.119 & 4.650 & 4.661 & 4.650 & 4.431 & 4.369 & 4.419 & 4.842 & 4.961 & 4.731 & 4.361 & 4.081 \\
\hline PEKAN BARU & 4.469 & 5.000 & 5.039 & 4.989 & 4.811 & 4.761 & 4.772 & 4.781 & 4.861 & 4.850 & 4.450 & 4.211 \\
\hline SEMARANG & 4.181 & 4.539 & 5.419 & 5.561 & 5.500 & 5.289 & 5.731 & 6.369 & 6.839 & 6.389 & 5.350 & 4.611 \\
\hline SURABAYA & 4.861 & 5.119 & 5.731 & 5.650 & 5.639 & 5.439 & 5.811 & 6.519 & 7.050 & 6.719 & 5.781 & 4.989 \\
\hline TANGERANG & 4.250 & 4.750 & 5.189 & 5.219 & 5.100 & 4.931 & 5.261 & 5.919 & 6.289 & 5.811 & 5.000 & 4.450 \\
\hline YOGYAKARTA & 4.200 & 4.369 & 4.461 & 4.600 & 4.581 & 4.419 & 4.650 & 5.089 & 5.489 & 5.361 & 4.689 & 4.519 \\
\hline
\end{tabular}




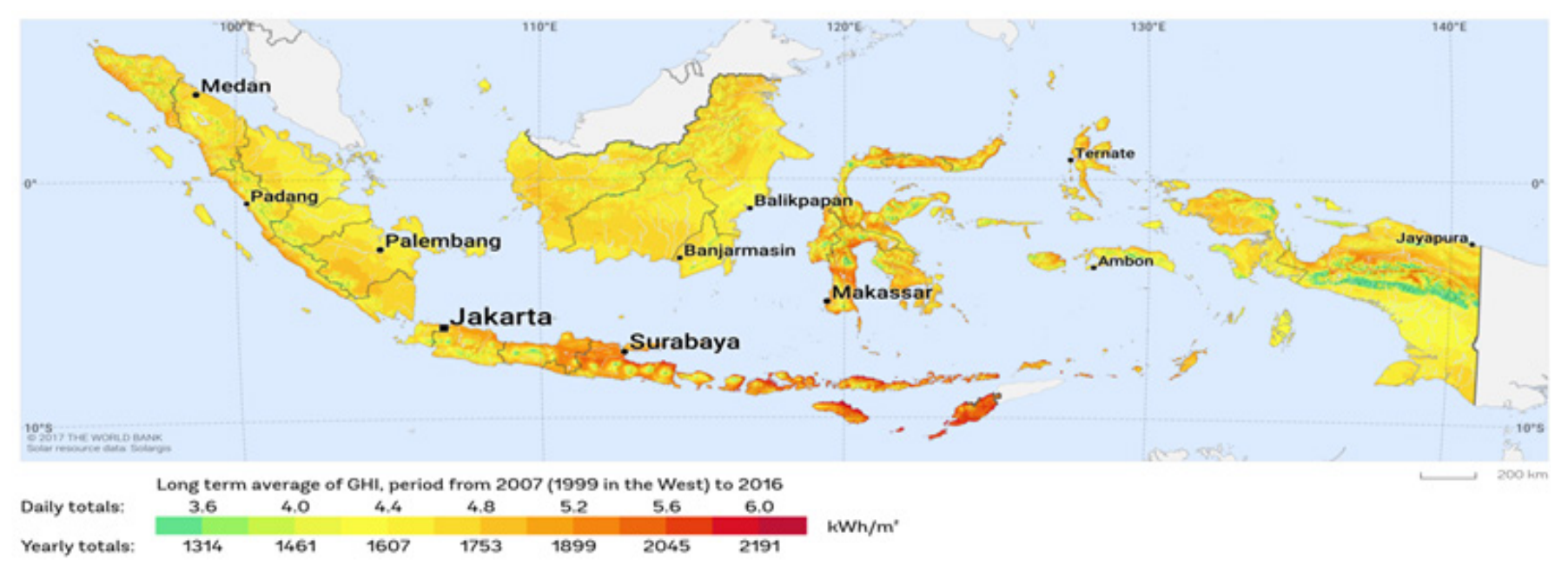

Figure 2: The average potential of electrical energy generated by solar panel installations ( $\mathrm{kWh} / \mathrm{kWp}$ ) in Indonesia

Table 3: The measurement data G-V-I of Polycrystalline PV Module

\begin{tabular}{|c|c|c|c|c|c|}
\hline $\begin{array}{c}\text { Local Time } \\
\text { (Hour:mnt) }\end{array}$ & $\begin{array}{c}\mathrm{G} \\
\left(\mathrm{W} / \mathrm{m}^{2}\right)\end{array}$ & $\begin{array}{c}\mathrm{I}_{\text {act }} \\
(\mathrm{Amp})\end{array}$ & $\begin{array}{c}\mathrm{V}_{\text {act }} \\
(\text { Volt })\end{array}$ & $\begin{array}{c}\mathrm{P}_{\text {act }} \\
(\text { Watt })\end{array}$ & $\eta(\%)$ \\
\hline $11: 00$ & 947 & 4.76 & 17.33 & 82.47 & 12.93 \\
\hline $11: 10$ & 1041 & 5.24 & 17.10 & 89.60 & 12.78 \\
\hline $11: 20$ & 1014 & 5.08 & 17.19 & 87.30 & 12.79 \\
\hline $11: 30$ & 1063 & 5.22 & 17.16 & 89.58 & 12.51 \\
\hline $11: 40$ & 1104 & 5.31 & 17.14 & 91.00 & 12.24 \\
\hline $11: 50$ & 1162 & 5.55 & 17.04 & 94.60 & 12.09 \\
\hline $12: 00$ & 1155 & 5.51 & 16.98 & 93.56 & 12.03 \\
\hline $12: 10$ & 1175 & 5.59 & 16.94 & 94.67 & 11.97 \\
\hline $12: 20$ & 1115 & 5.22 & 16.81 & 87.77 & 11.69 \\
\hline $12: 30$ & 1107 & 5.31 & 16.69 & 88.62 & 11.89 \\
\hline $12: 40$ & 1121 & 5.27 & 16.56 & 87.26 & 11.56 \\
\hline $12: 50$ & 1124 & 5.35 & 16.45 & 88.01 & 11.63 \\
\hline $13: 00$ & 1131 & 5.36 & 16.38 & 87.81 & 11.53 \\
\hline $13: 10$ & 1120 & 5.22 & 16.35 & 85.33 & 11.32 \\
\hline $13: 20$ & 1114 & 5.21 & 16.42 & 85.54 & 11.40 \\
\hline $13: 30$ & 1108 & 5.08 & 16.45 & 83.58 & 11.20 \\
\hline $13: 40$ & 1099 & 5.06 & 16.48 & 83.38 & 11.27 \\
\hline $13: 50$ & 1074 & 5.04 & 16.54 & 83.36 & 11.53 \\
\hline $14: 00$ & 1063 & 5.03 & 16.63 & 83.64 & 11.69 \\
\hline $14: 10$ & 1058 & 5.03 & 16.73 & 84.16 & 11.81 \\
\hline $14: 20$ & 1052 & 5.02 & 16.80 & 84.34 & 11.91 \\
\hline $14: 30$ & 1046 & 5.02 & 16.86 & 84.65 & 12.02 \\
\hline $14: 40$ & 1034 & 4.93 & 16.95 & 83.56 & 12.00 \\
\hline $14: 50$ & 1026 & 4.91 & 17.03 & 83.60 & 12.10 \\
\hline $15: 00$ & 1020 & 4.87 & 17.14 & 83.46 & 12.15 \\
\hline Average & 1082.92 & 5.17 & 16.81 & 86.83 & 11.92 \\
\hline & & & & & \\
\hline
\end{tabular}

The actual power (Pact) is the product of the output voltage and current from the installed PV Module installation. So can be calculated the amount of efficiency $(\eta)$ which is the ratio between the actual power and the received input power. The input power is generated from the calculation of the amount of solar radiation received $(\mathrm{G})$ and the area of the PV module (A). The experimental results for 4 hours (11.00-15.00), show the average solar radiation, output voltage and current, actual power, and efficiency of polycrystalline PV modules. The results are $\mathrm{G}=1082.92 \mathrm{~W} / \mathrm{m}^{2}$, lact $=5.17 \mathrm{~A}$, Vact $=16.81 \mathrm{~V}$, Pact $=86.83 \mathrm{~W}$, and $=11.92 \%$. Figure 3 shows the effect of solar radiation measurements on actual power. While Figure 4 shows the effect of solar radiation on the efficiency of polycrystalline PV modules

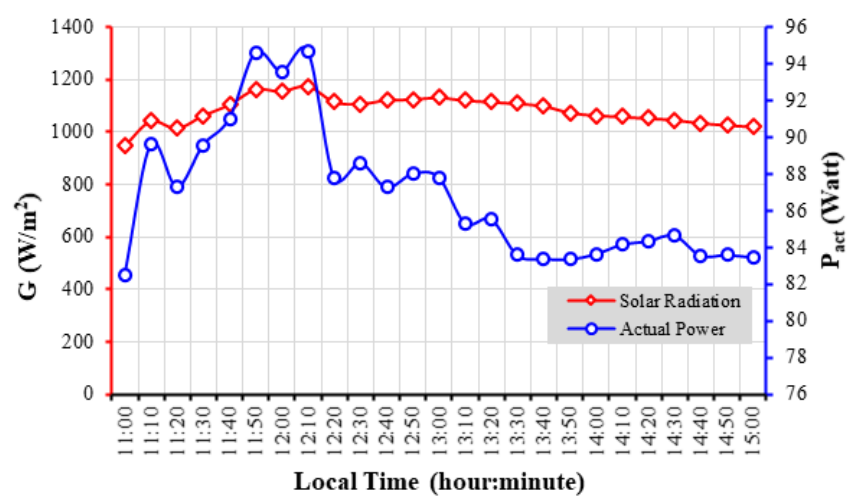

Figure 3: The effect of solar radiation with the actual power for the polycrystalline PV Module

Figure 3 shows for a certain period, when there is an increase in solar radiation, there is an increase in the actual power generated by the PV Module. The actual power is significantly reduced even though the received solar radiation is slightly reduced. While Figure 4 shows that when there is an increase in solar radiation, the efficiency of the solar panel decreases. However, after a gradual decrease in solar radiation, 


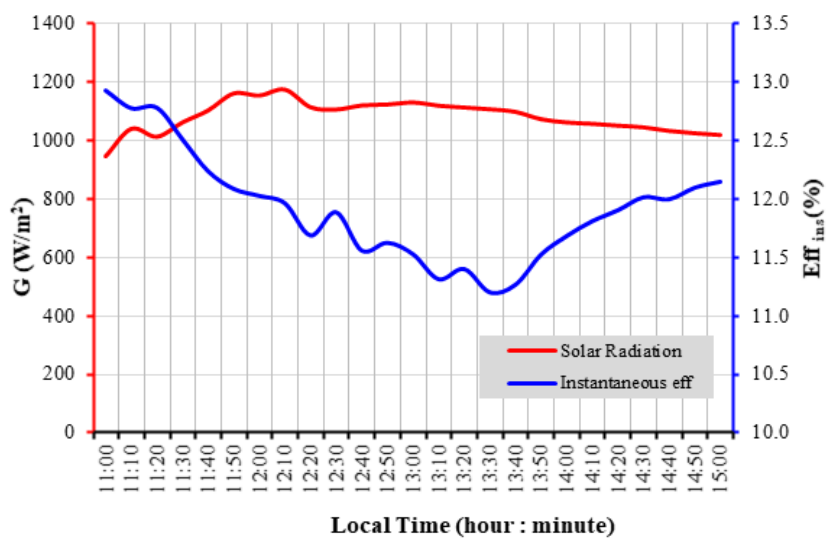

Figure 4: Effect of solar radiation with the Instantaneous efficiency of polycrystalline PV Module

there is an increase in the efficiency of the PV Module again. One reason is that when solar radiation is above $1000 \mathrm{~W} / \mathrm{m}^{2}$, the surface temperature of the module will increase. An increase in the surface temperature of the panel causes a decrease in the efficiency of the PV Module, especially for the polycrystalline type.

\section{The characteristics of actual power and efficiency of Amorphous PV Module}

Based on the results of testing the PV module for 4 hours (11.00-15.00 WIB), the average solar radiation, output voltage, current, actual power, and efficiency of the polycrystalline PV module. Each got $G=1082.92 \mathrm{~W} / \mathrm{m}^{2}, I_{\text {ac }}$ $=5.17 \mathrm{~A}, \mathrm{~V}_{\text {act }}=16.81 \mathrm{~V}, \mathrm{P}_{\text {act }}=86.83 \mathrm{~W}$, and $\eta_{\mathrm{i}}=11.92 \%$. Figure 5 and Figure 6 show the results of the measurement of solar radiation on the actual power and instantaneous efficiency of an amorphous PV module.

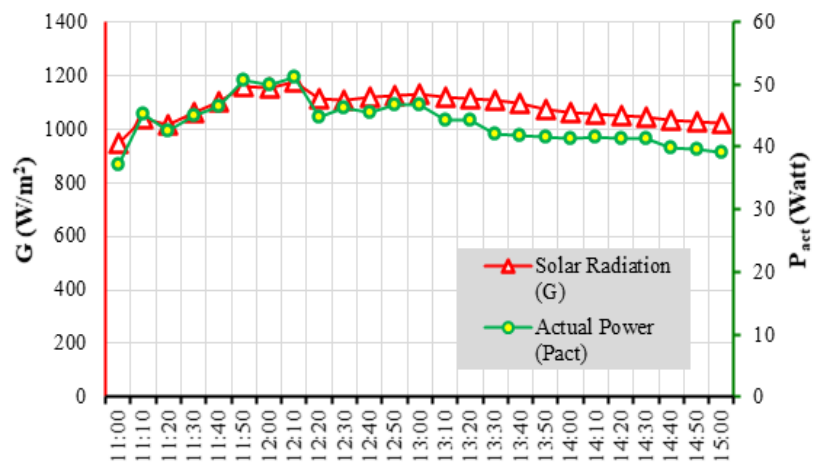

Local Time (hour:minute)

Figure 5: The effect of solar radiation on the actual power of the amorphous PV Module

Figure 5 shows that the increase or decrease in the actual power generated by the solar panels is almost proportional to the increase or decrease in the amount of solar radiation received. While Figure 6 shows that when there is an increase in solar radiation, there is an increase in the efficiency of the PV module. Therefore, the efficiency of solar panels decreases even though the amount of solar radiation received is only slightly reduced.
Table 4: the measurement data G-V-I of the amorphous PV Module

\begin{tabular}{|c|c|c|c|c|c|}
\hline $\begin{array}{c}\text { Local Time } \\
\text { (Hour:mnt })\end{array}$ & $\begin{array}{c}\mathrm{G} \\
\left(\mathrm{W} / \mathrm{m}^{2}\right)\end{array}$ & $\begin{array}{c}\mathrm{I}_{\text {act }} \\
(\mathrm{Amp})\end{array}$ & $\begin{array}{c}\mathrm{V}_{\text {act }} \\
(\text { Volt })\end{array}$ & $\begin{array}{c}\mathrm{P}_{\text {act }} \\
(\text { Watt }\end{array}$ & $\eta(\%)$ \\
\hline $11: 00$ & 947 & 2.16 & 17.25 & 37.26 & 5.84 \\
\hline $11: 10$ & 1041 & 2.64 & 17.18 & 45.36 & 6.47 \\
\hline $11: 20$ & 1014 & 2.48 & 17.21 & 42.68 & 6.25 \\
\hline $11: 30$ & 1063 & 2.62 & 17.20 & 45.06 & 6.30 \\
\hline $11: 40$ & 1104 & 2.71 & 17.19 & 46.59 & 6.27 \\
\hline $11: 50$ & 1162 & 2.95 & 17.16 & 50.63 & 6.47 \\
\hline $12: 00$ & 1155 & 2.91 & 17.14 & 49.89 & 6.41 \\
\hline $12: 10$ & 1175 & 2.99 & 17.13 & 51.22 & 6.47 \\
\hline $12: 20$ & 1115 & 2.62 & 17.09 & 44.78 & 5.96 \\
\hline $12: 30$ & 1107 & 2.71 & 17.05 & 46.21 & 6.20 \\
\hline $12: 40$ & 1121 & 2.67 & 17.01 & 45.42 & 6.02 \\
\hline $12: 50$ & 1124 & 2.75 & 16.98 & 46.69 & 6.17 \\
\hline $13: 00$ & 1131 & 2.76 & 16.96 & 46.80 & 6.15 \\
\hline $13: 10$ & 1120 & 2.62 & 16.95 & 44.40 & 5.89 \\
\hline $13: 20$ & 1114 & 2.61 & 16.97 & 44.29 & 5.90 \\
\hline $13: 30$ & 1108 & 2.48 & 16.98 & 42.11 & 5.64 \\
\hline $13: 40$ & 1099 & 2.46 & 16.99 & 41.79 & 5.65 \\
\hline $13: 50$ & 1074 & 2.44 & 17.01 & 41.49 & 5.74 \\
\hline $14: 00$ & 1063 & 2.43 & 17.03 & 41.39 & 5.78 \\
\hline $14: 10$ & 1058 & 2.43 & 17.07 & 41.47 & 5.82 \\
\hline $14: 20$ & 1052 & 2.42 & 17.09 & 41.35 & 5.84 \\
\hline $14: 30$ & 1046 & 2.42 & 17.11 & 41.40 & 5.88 \\
\hline $14: 40$ & 1034 & 2.33 & 17.13 & 39.92 & 5.73 \\
\hline $14: 50$ & 1026 & 2.31 & 17.16 & 39.63 & 5.74 \\
\hline $15: 00$ & 1020 & 2.27 & 17.19 & 39.03 & 5.68 \\
\hline Average & 1082.92 & 2.57 & 17.09 & 43.88 & 6.01 \\
\hline & & & & & \\
\hline
\end{tabular}

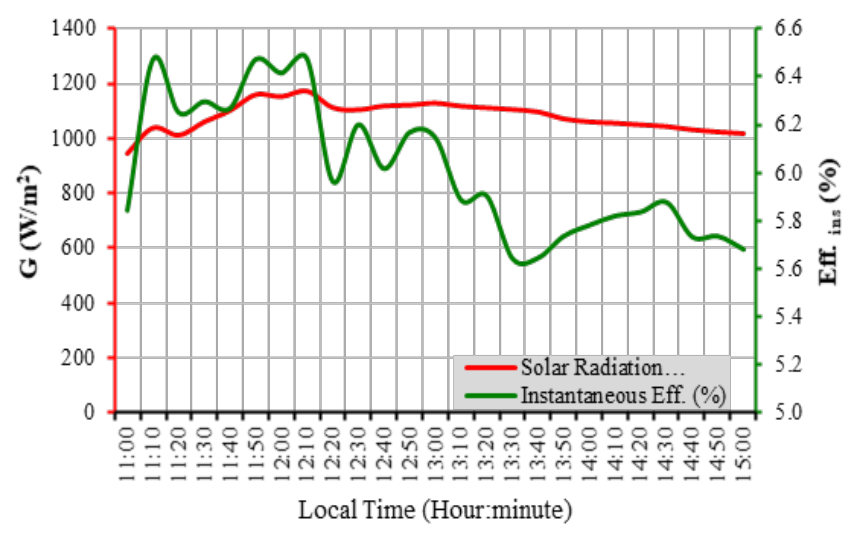

Figure 6: the effect of solar radiation on the instantaneous efficiency of the amorphous PV Module 
The comparison of instantaneous efficiency for Polycrystalline and Amorphous PV Modules

figure 7 shows determine the difference in the actual power generated by the polycrystalline and amorphous PV modules.

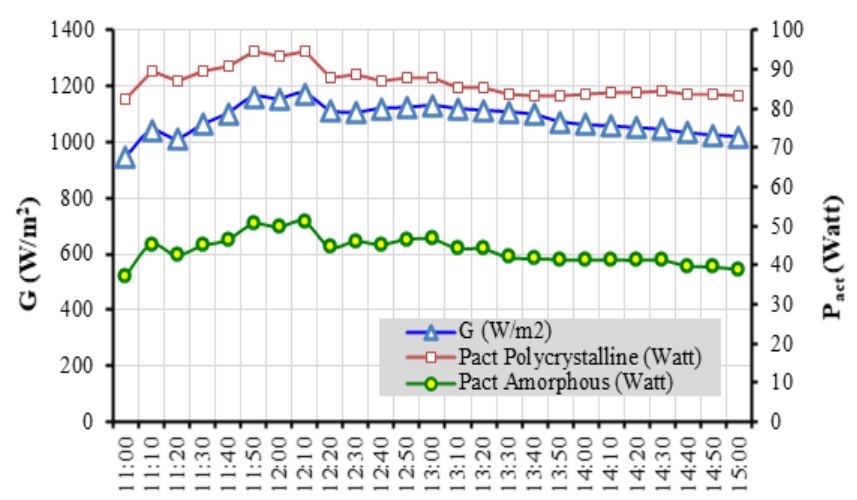

Local Time (hour:minute)

Figure 7: The comparison graph of the actual power of polycrystalline and amorphous PV Modules

The average actual power generated by the polycrystalline PV module is greater than the amorphous type, namely $86.83 \mathrm{~W}$ vs $43.88 \mathrm{~W}$. The difference between the capacity of the PV module, the polycrystalline type with a capacity of $100 \mathrm{Wp}$ and the amorphous type with a capacity of $80 \mathrm{Wp}$, the calculation of instantaneous efficiency to determine the objectivity performance. The results show that polycrystalline solar panels convert more solar radiation into electrical energy than amorphous solar panels; it is also seen that the increase or decrease in the actual power generated by the two types of solar panels is almost proportional to the increase or decrease in the amount of solar radiation received. Figure 8 shows the difference in the efficiency of polycrystalline and amorphous PV Modules.

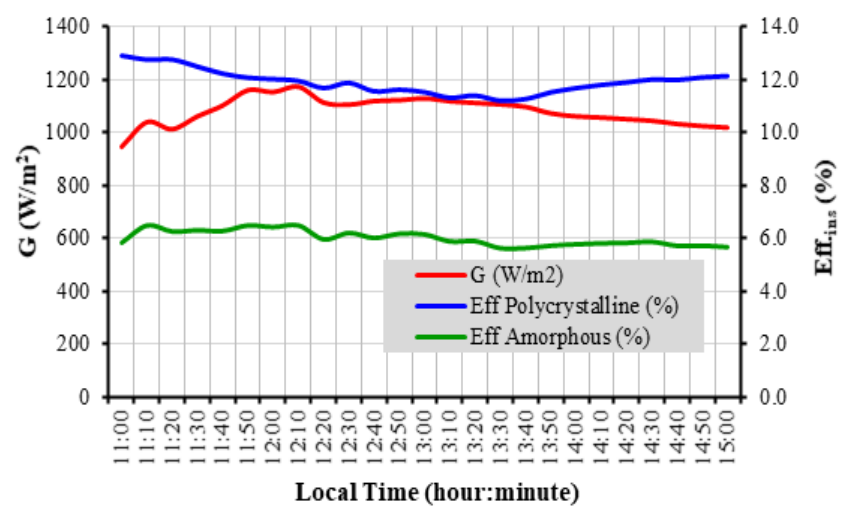

Figure 8: The comparison graph of the instantaneous efficiency of polycrystalline and amorphous PV Modules
The difference in the capacity of the solar panels, namely the polycrystalline type $100 \mathrm{Wp}$ and the amorphous type $80 \mathrm{Wp}$, affects the actual power output. From the comparison of the average efficiency of the two types of solar panels, it is found that the efficiency of the polycrystalline PV module (11.92\%) is greater than that of the amorphous type (6.01\%). Figure 8 shows that when there is an increase in the amount of solar radiation received, there is an increase in the efficiency of polycrystalline solar panels, then there is a significant decrease even though the amount of solar radiation received is only slightly reduced. This is different from amorphous solar panels, the instantaneous increase and decrease in efficiency that occurs due to the increase and decrease in the amount of radiation received is relatively stable. So amorphous type PV Modules produce more stable cost efficiency than polycrystalline solar panels.

\section{CONCLUSIONS}

The amount of solar radiation energy received by the PV module will affect the actual power generated by the solar panel. The greater the solar radiation, the higher the power generated by the solar panels. The polycrystalline type solar panel with a capacity of $100 \mathrm{Wp}$ can produce an average actual power of $86.83 \mathrm{~W}$. While the amorphous type $\mathrm{PV}$ module with a capacity of $80 \mathrm{Wp}$ produces an actual power of $43.88 \mathrm{~W}$. The polycrystalline PV modules have an average instantaneous efficiency (ni) which is higher than the amorphous type, namely $11.92 \%$ and $6.01 \%$, respectively. However, the amorphous produce a more stable average of instantaneous efficiency than the polycrystalline PV Module due to changes in the amount of solar radiation received. Therefore, with these amorphous characteristics, its use can be considered for areas that are often cloudy, such as Indonesia.

\section{ACKNOWLEDGEMENTS}

The author would like to express his appreciation to the Indonesian Ministry of Research. Technology and Higher Education (RISTEKDIKTI) and State Polytechnic of Malang for the support of this research sponsorship.

\section{REFERENCES}

1. Asrori, A., Suparman, S., Wahyudi, S., Widhiyanuriyawan, D. (2020). An experimental Study of Solar cooker Performance With thermal Concentrator System by spot Fresnel lens. Eastern-European Journal of Enterprise Technologies, 5 (8 (107)),31-41.doi:https://doi.org/10.15587/17294061.2020.208638.

2. M. H. Hasan, T. M. I. Mahlia, and H. Nur, "A review on energy scenario and sustainable energy in Indonesia," Renew. Sustain. Energy Rev., vol. 16, no. 4, pp. 2316-2328, 2012, doi: 10.1016/j.rser.2011.12.007. 
3. N. A. Handayani and D. Ariyanti, "Potency of solar energy applications in Indonesia," Int. J. Renew. Energy Dev., vol. 1, no. 2, pp. 33-38, 2012, doi: 10.14710/ijred.1.2.33-38.

4. M. Adouane, A. Al-Qattan, B. Alabdulrazzaq, and A. Fakhraldeen, "Comparative performance evaluation of different photovoltaic modules technologies under Kuwait harsh climatic conditions," Energy Reports, vol. 6, pp. 2689-2696, 2020, doi: 10.1016/j. egyr.2020.09.034.

5. E. Cuce, P. M. Cuce, I. H. Karakas, and T. Bali, "An accurate model for photovoltaic (PV) modules to determine electrical characteristics and thermodynamic performance parameters," Energy Convers. Manag., vol. 146, pp. 205-216, 2017, doi: 10.1016/j. enconman.2017.05.022.

6. S. Abdul-Ganiyu, D. A. Quansah, E. W. Ramde, R. Seidu, and M. S. Adaramola, "Investigation of solar photovoltaic-thermal (PVT) and solar photovoltaic (PV) performance: A case study in Ghana," Energies, vol. 13, no. 11, 2020, doi: 10.3390/en13112701.

7. A. H. Shnishil, S. S. Chid, M. J. Yaseen, and T. J. Alwana, "Influence of air mass on the performance of many types of PV modulus in Baghdad," Energy Procedia, vol. 6, pp. 153-159, 2011, doi: 10.1016/j. egypro.2011.05.018.
8. O. O. Ogbomo, E. H. Amalu, N. N. Ekere, and P. O. Olagbegi, "A review of photovoltaic module technologies for increased performance in tropical climate," Renew. Sustain. Energy Rev., vol. 75, pp. 12251238, 2017, doi: 10.1016/j.rser.2016.11.109.

9. B. Bechtel, "A new global climatology of annual land surface temperature," Remote Sens., vol. 7, no. 3, pp. 2850-2870, 2015, doi: 10.3390/rs70302850.

10. D. T. Cotfas and P. A. Cotfas, "Comparative Study of Two Commercial Photovoltaic Panels under Natural Sunlight Conditions," Int. J. Photoenergy, vol. 2019, 2019, doi: 10.1155/2019/8365175.

11. Asrori, A., Suparman, S., Wahyudi, S., Widhiyanuriyawan, D. (2020). Investigation of steam generation performance on conical cavity receiver by different geometric concentration ratios for fresnel lens solar concentrator. Eastern-European Journal of Enterprise Technologies, 4 (8 (106)), 6-14. doi: https://doi. org/10.15587/1729-4061.2020.209778.

12. G. Ciulla, V. Lo Brano, V. Franzitta, and M. Trapanese, "Assessment of the operating temperature of crystalline PV modules based on real use conditions," Int. J. Photoenergy, vol. 2014, 2014, doi: 10.1155/2014/718315.

13. Z. Usman, J. Tah, H. Abanda, and C. Nche, "A Critical Appraisal of PV-Systems ' Performance," pp. 1-22, 2020. 